\title{
A Linguistic Appraisal of Igbo Anthroponyms \\ by
}

\author{
Ifeoma Emmanuela Udoye \\ Chukwuemeka Odumegwu Ojukwu University \\ Igbariam Campus - Nigeria. \\ Faculty of Arts \\ E-mail: i.udoye@yahoo.com
}

\section{Abstract}

Naming has many times been relegated to the background whenever a linguistic study is involved. It is assumed that names are mere referent, therefore, are not useful in linguistic analysis. But, in actual sense, names are significant as they reflect on the social aspect of the society. Wakumelo, Mwanza \& Mkandawire (2016:270) noted that "...names or odonyms are not just mere signposts, they reflect the social, political, and cultural ideologies maintained by the name givers". In other words, names form a major part of the culture of any society and the Igbo people in particular in terms of their values, ideas, reflections, meanings and thoughts. Names identify, motivate and aspire the bearers. This paper discusses personal names among the Igbos of Nigeria and considers naming as an important aspect of the Igbo society. The paper looked at Igbo names within the purview of the grammatical categories. It was noted that Igbo names, like most names in Africa are mostly lexical, phrasal or compound with sentential underlying structures which make them unique and distinct from European personal names.

Key words: Personal names, naming, language, grammatical categories, Igbo 
Journal of Lexicography and Terminology, Volume 2, Issue 1

\section{Background}

\section{Ethnographic Information}

Igbo is the language of the people called Ndigbo. Igbos are one of the largest ethnic groups in Nigeria. According to Echeruo (2001), Igbo language is spoken by 20 million Nigerians. It is also one of the eight major languages spoken in Benue Congo group of African languages. The Igbo speaking people are mainly found in the South Eastern part of Nigeria. The states where Igbo is spoken are Enugu, Anambra, Ebonyi, Abia, Imo states and some parts of Delta and River states. Igbo language is incorporated in the school system and it is a compulsory subject from Primary to University levels especially, in Igbo speaking states such as the Chukwuemeka Odumegwu Ojukwu University, Uli, Anambra State.

\section{Igbo Anthroponyms}

Anthroponymy is the study of personal names which is a branch of Onomastics that deals with proper names, their forms and usage (Algeo, 2010). Names are used to identify and describe people, roads, buildings, play grounds, businesses with trademarks and other objects and facilities (Wakumelo, Mwanza \& Mkandawire, 2016). Furthermore, Chanda-Tembo (2017:115) reported that "business names like brands and trademarks are economic devices that play instrumental roles in differentiating businesses from other businesses in the course of trade". Similarly, personal names like business names, play significant roles in people's lives as they are used for identity and other social commentaries. For instance, in the case of Igbos, personal names are symbolic. They provide an insight into their culture, philosophy, religion, language and environment. Igbo personal names like most African 
names have all the qualities, attributes and world view which Igbo men and women cherish and honour. The main focus of the paper was to provide some Igbo names and analyse their grammatical structures. The names were presented and examined under three main headings: lexical, phrasal and sentential personal names.

\section{The Nature of Names}

\section{Lexical Personal Names}

Lexical personal names are those names which are structured to have simple nouns. One characteristic feature of these lexical personal names is that such names have vowel initial syllable. Consider the following examples:
(1) enyí -
$\mathrm{V}-\mathrm{C}-\mathrm{V}$
'elephant'
(2) $\operatorname{eg} \bar{u}_{\mathrm{i}} \quad-$
$\mathrm{V}-\mathrm{C}-\mathrm{V}$
'tiger'
(3) egwé -
$\mathrm{V}-\mathrm{C}-\mathrm{V}$
'sky'
(4) egó
$\mathrm{V}-\mathrm{C}-\mathrm{V}$
'money'
(5) ugò
$\mathrm{V}-\mathrm{C}-\mathrm{V}$
'eagle'

The personal names 'elephant', 'tiger', 'sky', 'money', 'eagle', represent the idealised subjective perceptions which the giver of the name had in mind hence, personal names are said to connote the aspirations the giver has for the child. The giver of the name wants the bearer to have the qualities of the animals which they are named after. Enyi 'elephant' is regarded as very strong and brave, Odum 'lion' is brave, Agu 'tiger' is a strong fighter that is fearless'. It is believed that the names would spur on the bearers to conform to the expectations of the name.

\section{Phrasal Personal Names}

A phrase is a syntactic unit that can be headed by a noun, 
adjective, adverb, verb or preposition. Phrasal personal names are those names that are derived from verb phrase or nominal compound. According to Quirk et al (1985) there is no clear boundary between a noun phrase and a noun+ noun compound. They further observed that the decisive features are stress on the first syllable (in case of Compound) and possibility of substituting one for the second constituent (in case of a phrase). Also, Lees (1960) opines that nominal compounds indicate the difference in grammatical form embedded within the compounds. Therefore, in this paper, all personal names with noun+ noun phrases are treated as nominal compounds.

\section{The Nominal Compound}

Noun according to Fromkin et al (2003) is a lexical or syntactic category of words that function as the head of a noun phrase. It is also known as nominal. The following are examples in English Language:
(6) Philip
(7) Agnes
(8) America
(9) Dog

While, compounding is effected when two or more nouns are joined together to form one word. A compound noun is made up of two or more nouns that function as a single noun which can either be written as separate words or linked by hyphens. Examples are provided below:

English Compounds

(10) Black-board

(11) House coat 
Journal of Lexicography and Terminology, Volume 2, Issue 1
(12) Arm chair
(13) Book-shelf

\section{Igbo Compounds}

The examples below reflects the Igbo compounds. Note that a full form is provided, followed by analysis.

(14) úlòákwúkwó, 'a school' (úlòákwúkwwó, is a compound word)

úlò $\quad$ ákwúkwó,

house book

(15) nwada 'a girl child' (nwada is a compound word)

nwa ada

child daughter

(16) nwánnē 'my brother/sister' (nwánnē is a compound word)

nwá nnē

child mother

(17) nwájí ‘small yam' (nwájí is a compound word)

nwá jí

child yam

(18) ákáèkpè 'left hand' (ákáèkpè is a compound word) áká èkpè hand left

(19) ónyénkúzí 'teacher' (ónyénkúzí is a compound word) ónyé nkúzí 
Journal of Lexicography and Terminology, Volume 2, Issue 1

person teacher

(20) nwáéhí 'calf' (nwá éhí is a compound word)

$\begin{array}{ll}\text { nwá } & \text { éhí } \\ \text { child } & \text { cow }\end{array}$

it is important to note that the nominal compound has two names labelled as noun 1 and noun $2(\mathrm{~N} 1+\mathrm{N} 2)$. This group is most productive in Igbo personal names. Example:

N1 + N2

(21) Àdáèzè 'first daughter of a king' (Àdáèzè is a compound name)

Àdá èzè ‘

first daughter king

(22) Ódùágú 'a precious child' (Ódùágú is a compound name)

Ódù ágú

tail tiger

(23) Ùgòchúkwú 'God's eagle' (Ùgòchúkwú is a compound ame)

Ùgò Chúkwú

eagle God

(24) Àdáùgò 'a daughter of high esteem' (Àdáùgò is a compound name)

Àdá ùgò

daughter eagle

(25) Ùgòékè 'a pretty child born on Eke market day' (Ùgòékè is a compound name)

Ùgò ékè 
Journal of Lexicography and Terminology, Volume 2, Issue 1

eagle traditional Igbo market day

(26) Ákáchúkwú 'handiwork of God' (Ákáchúkwú is a compound name)

Áká chúkwú

hand God

(27) Ányándù 'eyes of life' (Ányándù is a compound name) Ányá ndù

eyes life

(28) Àkùézè 'wealth of a king' (Àkùézè is a compound name)

Àkù ézè

wealth king

(29) Úzòchúkwú 'God's path' ( Úzòchúkwú is a compound name)

Úzò chúkwú

road God

In Igbo personal name, there is no complementary distribution restriction placed on 'Ugo' as could be found in Igbo title names. 'Ugo' could occupy either the N1 position when the N2 is [+animate] nor is it relegated to N2 position whenever it cooccurs with a [-animate] noun. Example:

(30) Ójịuugò 'a beautiful wife' ( Ójịùgò is a compound titlename)

Ójí ùgò

kolanut eagle

Becomes ungrammatical and unacceptable when it is in reverse order 


$$
\begin{array}{ll}
\text { (31) *Ùgò } & \text { ójī } \\
\text { eagle } & \text { kolanut }
\end{array}
$$

However, 'Ugo Oji' is a grammatical acceptable personal name borne by many people.

\section{Prefixation of Nouns}

Anagbogu et al (2010) defined prefix as an affix which occurs in word-initial position. In Igbo language, prefixes are only attached to the verb (Agbedo, 2000). However, in Igbo personal names prefixation could be attached to a verb or a noun which are usually found in Igbo Ukwu (and other Aguata towns) and Awka personal names. In Igbo Ukwu, a dialect of Igbo, 'Ume' (Eze 'king) is obligatorily prefixed (Okafor, Emeka \& Inyiama, 2008). Examples:

(32) Úméíbè 'king of my neighbour' (Úméíbè is a personal name)

Úmé Íbè

king clan

(33) Úménwéké 'king of the child of Eke' (Úménwéké is a personal name)

Úmé Nwéké

king child of Eke (a god)

(34) Úméánòwái 'king of with time the truth will be remembered' (Úméánòwáí is a personal name)

Úmé Ánòwáí

king with time the truth or cherished value will be remembered 
Journal of Lexicography and Terminology, Volume 2, Issue 1

(35) Úméúdé 'king of fame' (Úméúdé is a personal name) Úmé Údé king fame

(36) Úméánòliéfó 'king of people to be remembered for their good works' (Úméánòliéfó is a compound name) Úmé Ánòliéfó king people remembered for their good works

On the other hand, Awka dialect has the prefix 'nwa' which occurs with all [+animate] entities and names. However, prefixation of 'nwa' is not mandatory. Example:

(37) Nwáiféómá 'child of good thing' (Nwáiféómá is a per sonal name)

Nwá Íféómá

child good thing

(38) Nwáchíomá 'child of good god' (Nwáchíómá is a personal name)

Nwá

Chíómá

child god good

(39) Nwáòkèchúkwú 'child of God's apportionment' (Nwáòkèchúkwú is a personal name)

Nwá

Òkèchúkwú

Child portion God

(40) Nwángózí ‘child of God's blessing' (Nwángózí is a per sonal name)

Nwá Ngózí

child blessing 
Journal of Lexicography and Terminology, Volume 2, Issue 1

(41) Nwánkírúkà 'child of the best is yet to come' (Nwánkírúkà is a personal name)

Nwá

Nkírúkà

child

what is in front

Awka indigenes have wondered how prefixation of 'nwa' became a pattern for addressing all other names, except for the names that specify the four native week Nkwo, Eke, Oye and Afo and individuals bear such names as Nwaeke, Nwaoye, Nwaafo, Nwankwo.

\section{Sentential Personal Names}

Sentential personal names are those names that have sentences as their base. Grammatically, sentential personal names can also be called sentential nominalisations. Sometimes, some sentential personal names may appear to be lengthy by the bearer who may shorten it as observed by Kammelu (2008). Example:

(42) Chétàchúkwú 'remember God' (Chétàchúkwúa sentential personal name)

Chétà chúkwú

remember God

*Cheta 'remember'

(43) Mmésòómáchúkwu

'God's

goodness'

(Mmésòómáchúkwu is a sentential name)

Mmésòómá chúkwu

goodness God

*Mmèè 'blood'

(44) Ogùàghaláriam 'may warnever fail me'(Ogùàghaláriam is a sentential name) 
Journal of Lexicography and Terminology, Volume 2, Issue 1

$\begin{array}{ll}\text { Ogù } & \text { àghaláriam } \\ \text { war } & \text { left me } \\ \text { *Ogùghá 'war failed me' }\end{array}$

But, the bearer often answers 'Cheta' which is the reduced or shortened form. Sentential personal names can be grouped into three broad sentence types such as declarative, interrogative and imperative.

\section{Declaratives Sentence Names}

Declarative is the normal way to conveying a statement in a language. It makes a statement of opinion or fact in an assertive way. Consider the example below:

(45) Ngozi is a bank manager.

Personal names in this category are most numerous. They vary from simple sentences of the N-V-N structure to more complex sentences. However, the N-V-N sentence structure is very commonly used.

$\mathrm{N} \quad \mathrm{V} \quad \mathrm{N}$

(46) Chíbụeézè 'God is the overall king' (Chíbụézè is a declarative personal name)

Chí bù̀ ézè

God is king

(47) Chíbừísí 'God is the head' (Chíbùézè is a declarative per sonal name)

Chí bù ị́sí

God is head

(48) Chíbụ̀àù 'God gives wealth' (Chíbụ̀àụ̀ is a declarative personal name)

Chí bù̀ àkụ̀ 
Journal of Lexicography and Terminology, Volume 2, Issue 1

God is wealth

(49) Chíbùndụ̀ 'God is the giver of life' (Chíbụ̀ndụ̀ is a declarative personal name)

Chí bù̀ ndụ

(50) Chíjìnwa 'God holds the child' (Chíjìnwa is a declarative personal name)

Chí jì nwa

God holds child

(51) Chínènyénwá 'God gives children' (Chínènyénwá is a declarative personal name)

Chí nènyé nwá

God gives child

(52) Chúkwúbụ̀nnà 'God is fatherly' (Chúkwúbụ̀nnà is a declarative personal name)

Chúkwú bù̀ nnà

God is father

(53) Ézèbù̀chí the king is a god '(Ézèbụ̀chí is a declarative personal name)

$\begin{array}{lll}\text { Ézè } & \text { bù } & \text { chí } \\ \text { king } & \text { is } & \text { personal god }\end{array}$

The declarative personal names above perform two functions. The first one is that it is a lexicalised sentence and the second one is that the names are used to denote an entity just like a single lexical item. 
Journal of Lexicography and Terminology, Volume 2, Issue 1

\section{Interrogative Personal Names}

Interrogative is primarily used to ask question which is often accompanied by a question mark Ofomata (2007). Additionally, the listener is expected to give answer to the question asked. Crystal (2003) classified interrogatives into three main types which are: Polar questions, Wh-questions and the Alternative questions.

In interrogative statements or sentences, the hearer is expected to provide some information for the speaker in a situation whereby the sought information may already be accessible to both the speaker and the hearer, interrogatives would now be used to emphasise the intention of the speaker. Example
(54). Ò zùrùóhíégó? 'did he steal money'
(55) Ò gbàràégwú? 'did she dance?

In Igbo language, Emenanjo (2015) observed that Igbo interrogatives are marked by tone patterns particularly low tones. There are specific words in Igbo which are known as question words. They are:
(56) Gịnī - what
(57) Kèdú - how
(58) Òlèē - $\quad$ where, which, how, when
(59) Ònyé - who

\section{Examples of personal names with gini'what':}

(60) Gịinịkàchúkwú Gínī kà whatgreater 'what is greater than God?' chúkwú

(61) Gịinịfòlù 'what else remains?' Gị́nị fòlù 
Journal of Lexicography and Terminology, Volume 2, Issue 1 whatremains

\section{Personal names with Olee examples}

62 Òléēkànmá 'which is better'

Òléēkà nmá

which greater fine

(63) Òlébụ̀nné 'which among them is the mother' Òlé bù̀ nné which is mother

(64) Òléjìndù 'how many people hold life' Òlé jì ndù which holds life

(65) Òlékànjọ́ 'which is worse than others' Òlé kà njọ which greater sin

(66) Òlékàibè 'who is greater than his fellows' Òlé kà njó which greater fellow

\section{Personal names with Kedu}

(67) Kèdúónyékáchúkwú 'who is greater than God' Kèdú ónyé ká chúkwú who person greater God

Personal names with $K e d u^{6}$ who' are scanty in Igbo personal names. However, it is hoped that new generation parents would 
Journal of Lexicography and Terminology, Volume 2, Issue 1 coin names to reflect the question tag 'kedu'.

\section{Imperatives Personal Names}

Imperatives give command, make a request or express a wish.

Example: Get out of my car

In Igbo, most imperatives use the verb stem without any prefix such as:
(68) Nyé - give
(69) Gwá- tell

Imperatives can also be followed by a noun or pronoun. Example:
(70) Nyé m égō - ' 'give me money'
(71) Gwá m - c ctell me'
(72) Kwùóyā - 'say it'

Imperatives are punctuated with a simple full stop or exclamation mark depending on the strength of emotion the speaker wants to express. This sub-group is the least productive of all the sentence types involved in sentential nominalisations. The structure is an imperative verb $+\mathrm{NP}$ or $\mathrm{NP}+\mathrm{S}$.

Examples:

(73) Zèeụùà 'avoid the world'

Zèé ù̀wà $(\mathrm{V}+\mathrm{N})$

avoid world

(74) Zèlúnjó ‘avoid sin'

Zèlú

njó $(\mathrm{V}+\mathrm{N})$

avoid

$\sin$

(75) Zèéíbè 'avoid people'

Zèé íbè $(\mathrm{V}+\mathrm{N})$ 
Journal of Lexicography and Terminology, Volume 2, Issue 1

avoid relations

(76) Gwáchí 'tell God about your problems'

Gwá chí $(\mathrm{V}+\mathrm{N})$

tell God

(77) Gwánírú 'talk to me face to face'

$\begin{array}{lll}\text { Gwá nírú } & (\mathrm{V}+\mathrm{N}) \\ \text { tell } & \text { face } & \end{array}$

From the above analysis of Igbo names, it is worthy to also highlight some obvious differences that exist between Igbo and British personal names. Because the linguistic structure of Igbo is quite different from the European personal names particularly the British personal names. British names cannot be analysed linguistically like the Igbo names above. Consider the examples below:

\section{English Names}

$\begin{array}{ll}\text { (78) Wright } & \text { 'carpenter' } \\ \text { (79) Green } & \text { 'wearer of green ' } \\ \text { (80) Walker } & \text { 'thickener of woollen cloth' } \\ \text { (81) Hall } & \text { 'walker near a hall' } \\ \text { (82) White } & \text { 'fair hair' }\end{array}$

Additionally, in British personal names, compound personal names only occur in surnames where women combine their parents surname and their husbands' surnames. The reason for this combination is to enable them to preserve their family name particularly in families where there are no male descendants and also for inheritance of a family estate (Rosseinsky 2017). Some 
Journal of Lexicography and Terminology, Volume 2, Issue 1 notable persons' compound names are as follows:

Name

(83) Ralph Vaughan William

(84) Robert Hanbury Brown

(85) Kristin Scott Thomas

(86) Helena Bonham Carter

\section{Occupation}

Composer

Astronomer

Actor

Actor

It is worthy to note that affixation of a hyphen is often optional in English compound personal names (Rosseinsky 2017). English names, unlike, Igbo names, reflect the etymology of names (Parkin, 2014) rather than the connotative use of names which is applicable in Igbo. Such names are derived from the bible, saints, Celtic tradition, and names brought in through invasion( Chursina, 2011; Reaney\& Wilson 2006) . English names are also used to distinguish class whether the bearer of the name comes from a working class or middle class or upper class family which is not obtainable in Igbo personal names (Reaney\& Wilson 2006; Clarke \&Cummis (2013).

Furthermore, British names have cognates. This implies that names have two variants one for a male and the other for a female. Consider the following examples

Male

(87) Oliver

(88) Christian

(89) Emmanuel
Female

Olivia

Christiana

Emmanuela

\section{Conclusion}

Naming is an important aspect of linguistics because there is hardly any meaningful linguistic discourse in a language that 
does not make reference to proper nouns. With this, personal names can serve as a more authentic source of evaluating language. The paper sought to analyse Igbo anthroponyms from a linguistic perspective. The study discussed the various grammatical categories which revealed that some Igbo names are lexical items. The study also found out that nominal compounds are the most productive phrasal or compound personal names while declarative sentential names were the most numerous in number among the Igbo community. It was further revealed that imperative sentential names were the least productive.

\section{References}

Agbedo, C. (2015). General linguistics: Historical and contemporary perspective. Nsukka:

Kumcee Ntaeshe Press inc.

Algeo, J. (2010). Is a theory of names possible? Names Journal of Onomastics, 58 (2), 90- 97.

Anagbogu, P., Eme, C., \& Mbah, B. (2010). Introduction to Linguistics. Awka: J.F.C Limited.

Chanda-Tembo, N. (2017). What is in a Name? Assessing the Limitations in the Conceptualisation of Business Names of Local Small Scale Vending Businesses in Zambia. Journal of Lexicography and Terminology, 1(1), 115-129.

Chursina, I. (2011). Morphonological changes in the middle English personal names. Synergy, 7(1), 67-72.

Clark, G \& Cummins, N, (2013). Surnames and social mobility:

England $1230-2012$.

Economic History Working Papers. 181, 1-26.

Crystal, D. (2003). The Cambridge encyclopaedia of the English language. Cambridge: Cambridge Press.

Echeruo, M. (2001). Igbo English dictionary. Lagos: Longman. Emenanjo, N. (2015). A grammar of contemporary Igbo: 
Constituents, features and processes. Port Harcourt: M\&J Grand Orbit Communications.

Fromkin, V., Rodman, R., \&Hyans, N. (2003). An introduction to language. Boston: Wadsworth.

Kammelu, N. (2008). Reconstruction of Igbo personal names: The phono-semantic implications. In I.Ikwubuzo, C. OhiriAniche and C. Nnabuihe (eds), Udezuluigbo A Festschrift in Honour of Sam Uzochukwu, pp. 208-223.

Lees, R.B. (1960). The grammar of English nominalization. Bloomington:Mouton.

Ofomata,C.(2007).NdezuutoasusuIgbo:Usoronkuzinaomumunke $U B E$. Enugug: Format Publishers Nigeria Ltd.

Okafor, R, Emeka,L., \&Inyiama. T. (2008). Igbo personal and title names. Enugu: New Generation Books.

Parkin, D.H (2014). Change in the by names and surnames of the Cotswolds. ( $\mathrm{PhD}$ Thesis, University of West of England, Bristols, England).

Quirk, R, Sidney, G, Geoffery, L\& Jan, S. (1985). A comprehensive grammar of English language. London: Longman

Reaney, P \& Wilson, M. (2006). A dictionary of English surnames (e-book).Retrieved from http//Taylor \&Francis ebookstore. tanf.co.uk/.

Rosseinsky, K. (2017, September 12). Everything you should know before getting a double barrelled surname. Grazia. Retrieved from https//www.graziadaily.co.uk/real-life double barrelled-surnames

Wakumelo, M., Mwanza, D. S. \& Mkandawire, S. B. (2016). The toponymics of postcolonial Zambia: Street naming patterns in Lusaka. In O. Nyambi, T. Mangena\& C. Pfukwa (Ed.), The Postcolonial Condition of Names and Naming Practices in Southern Africa (PP. 270288). Newcastle, Uk: Cambridge Publishing Scholars 